\title{
平面上突起対まわりのはく離流れと熱伝達の数值解析*
}

\author{
吉 川 浩 行*1, 和 久 貴 志 $^{* 2}$ \\ 中島 円*3, 太田照和*1

\section{Numerical Simulation of Separated Flow and Heat Transfer Around a Pair of Rectangular Blocks on Flat Surface}

\author{
Hiroyuki YOSHIKAWA*4, Takashi WAKU, \\ Madoka NAKAJIMA and Terukazu OTA \\ ${ }^{* 4}$ Department of Machine Intelligence and Systems Engineering, Tohoku University, \\ 01 Aramaki-Aoba, Aoba-ku, Sendai-shi, Miyagi, 980-8579 Japan
}

\begin{abstract}
Numerical results simulating a three-dimensional separated flow and heat transfer around surface-mounted rectangular blocks in a plane channel are presented. Flow configuration treated in the present study is transversal two blocks. The finite difference method is employed to directly solve Navier-Stokes, continuity and energy equations, and resulting finite difference equations are solved with the SMAC method in Reynolds number range from 100 to 500 . Present results are compared with available flow visualization ones and it is found that the present numerical method well simulates the observed results such as horseshoe vortices and the recirculating separated flow. Local and mean heat transfer characteristics are clarified and their correlations with the flow structure are investigated.
\end{abstract}

Key Words : Forced Convection, Separated Flow, Numerical Simulation, Pair of Rectangular Blocks

\section{1. 緒}

\section{言}

壁面上に固定された突起物は多くの流体機械や熱交 換器等に見られるため, そのような物体まわりの流れ と熱伝達の詳細な把握は工学上重要であり, 従来から 数多くの研究 (1)-(8) が行われている. 突起物のまわり には馬蹄形渦が形成され，大規模渦が後流へと放出さ れるなどきわめて三次元性が強いこと, 流れ場は突起 物の形状, レイノルズ数および突起上流側の境界層の 特性に大きく依存すること等が明らかにされている.

一方, コンピュータに代表される電子機器において, 小型高速化による単位体積当りの発熱量の増加は著し く, 冷却技術の向上が重要になっている. IC パッケー ジ周囲の流れ場と熱伝達機構の詳細を明らかにするた め, 基礎的な形状とみなせる平面上に設置された突起 物まわりの流れ場, 温度場に関する研究 (9)-(17) も数 多くなされている. 著者ら (18)-(21) は平行壁面流路内 単一突起物まわりの三次元流れと熱伝達の数值解析を

* 原稿受付 2003 年 10 月 17 日.

*1 正員, 東北大学大学院工学研究科( 980-8579 仙台市青葉 区荒巻字青葉 01).

*2 (株) 本田技術研究所 (351-0193 和光市中央 1-4-1).

*3 正員, 金沢工業大学工学部航空システム工学科(- 921-8501 石川県石川郡野々市町扇が丘 7-1).

E-mail : yoshi@cc.mech.tohoku.ac.jp
行い,レイノルズ数による流れ場および熱伝達特性の 変化を明らかにしている.

複数の突起物まわりの研究 ${ }^{(22)-(26)}$ も行われている が，そのほとんどは突起面平均熱伝達に関するもので ある. Meinders ら (27) は加熱された 5 個の立方体を 平行壁面流路内に主流方向に配置し, 赤外線サーモグ ラフィにより立方体表面の局所熱伝達率を測定し,レ イノルズ数による熱伝達特性の変化を明らかにした. Garimella と Eibeck ${ }^{(28)}$ は格子状に配列された流路内 突起物まわりの流れ場に関する実験を行い, LDVを 用いて突起間の平均速度を測定し, 突起間隔およびレ イノルズ数による速度場の変化を示した. 岡本ら (29) は平面壁上に格子状および千鳥状に配列された突起列 まわりの流れに関する実験を行い，LDV を用いて速 度場を測定し, 突起間隔および配列による流れ場の変 化を明らかにした．著者ら ${ }^{(30)}$ は主流方向に一対の突 起物を有する平行壁面流路内三次元流れと熱伝達の数 值解析を行い, 突起間隔, レイノルズ数による流れ場 および熱伝達特性の変化を明らかにした. しかしなが ら，突起物まわりの流れは三次元的で非常に複雑であ り，流れ場と温度場の詳細は十分に解明されていると は言い難い. 
以上のような背景から, 本研究では, 主流と直交方 向に一対の同一直方体突起物が設置され, 突起間すき まが突起高さの $0.2 \sim 2.0$ 倍の場合を取り上げ, 平行壁 面流路内三次元流れと熱伝達の数值解析を行い, 流れ 場, 温度場および熱伝達特性の詳細を明らかにしよう とするものである.

\section{2.おもな歫号}

$C_{f}:$ 壁面摩擦係数 $=\tau_{w} /\left(\rho U_{0}^{2} / 2\right)$

$H:$ 流路高さ

$h:$ 突起高さ

$L, W:$ 主流およびスパン方向突起幅

$N u:$ ヌッセルト数 $=\alpha h / \lambda$

$\operatorname{Pr}:$ プラントル数

$p:$ 圧力

$q_{w}:$ 熱流束

$R e:$ レイノルズ数 $=U_{0} h / \nu$

$s:$ スパン方向突起間すきま

$t:$ 時間

$U_{0}$ : 入口平均速度

$\boldsymbol{u}:$ 速度ベクトル $(u, v, w)$

$x:$ 座標 $(x, y, z)$

$\alpha:$ 局所熱伝達率 $=q_{w} /\left(\theta_{\boldsymbol{w}}-\theta_{0}\right)$

$\Delta C_{p}$ : 圧力損失 $=\Delta p /\left(\rho U_{0}^{2} / 2\right)$

$\theta:$ 温度

$\lambda:$ 熱伝導率

$\nu, \rho:$ 動粘度および密度

$\tau_{w}:$ 壁面摩擦応力

添 字

$0:$ 入口での值

$m:$ 平均值

$w:$ 壁面での值

$x:$ 主流方向成分

- : 時間平均値

\section{3. 基礎方程式および数值解法}

本研究では三次元非圧縮粘性流れを取扱う。図 1 に 平行壁面流路内の突起物の配置, 座標系およびおもな 記号を示す. $h$ は突起高さ， $H$ は流路高さ， $L, W$ は それぞれ主流およびスパン方向突起幅， $s$ は突起間す きまである. 支配方程式は次に示す連続の式，ナビエ. ストークスの運動方程式，エネルギー方程式である.

$$
\begin{gathered}
\nabla \cdot \boldsymbol{u}=0 \\
\boldsymbol{u}_{t}+(\boldsymbol{u} \cdot \nabla) \boldsymbol{u}=-\nabla p+\frac{1}{R e} \nabla^{2} \boldsymbol{u} \\
\theta_{t}+(\boldsymbol{u} \cdot \nabla) \theta=\frac{1}{R e P r} \nabla^{2} \theta
\end{gathered}
$$

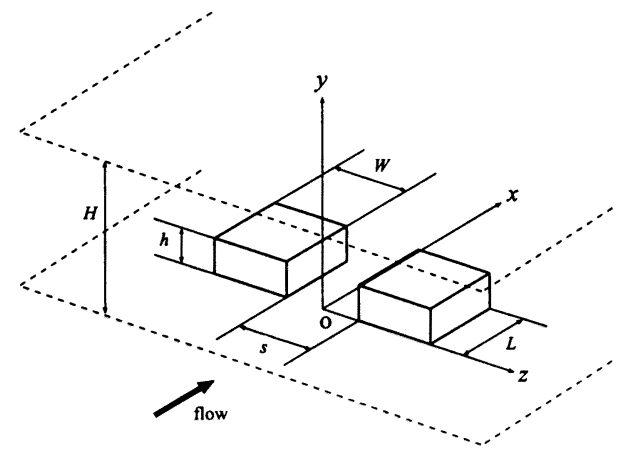

Fig. 1 Flow configuration and coordinate system

ただし上式で, 座標, 時間, 速度, 圧力および温度 はそれぞれ $\boldsymbol{x}^{*}=x / h, t^{*}=t U_{0} / h, u^{*}=u / U_{0}$, $p^{*}=p / \rho U_{0}^{2}, \theta^{*}=\lambda\left(\theta-\theta_{0}\right) / q_{w} h$ と無次元化されてい る.ここで，添字*は無次元量を表すが，上式では省 略している．上式の解法には既報 (31) と同様 SMAC 法 (32) を用いる. 時間微分については, 対流項, 粘性 項に 2 次精度 Adams-Bashforth 法, 圧力項に Euler 後退差分を適用し，時間進行を行った. 空間微分につ いては, 対流項に 5 次精度上流差分, 粘性項に 4 次精 度中心差分を用いて離散化した. また，圧力補正のポ アソン方程式に 2 次精度中心差分を用いた。

境界条件は，速度については，入口で放物線速度分 布, 壁面で滑りなし, 出口で一階微分零，スパン方向 境界で対称条件とした，温度については，入口で一様 温度, 突起全面で熱流束一定, その他の壁面で断熱, 出口およびスパン方向境界で二階微分零とした.

本計算では, 計算領域は, 突起前方に $10 h$, 突起後 方に $30 h$, 突起側方に $12 h$ とし, 流路高さ $H / h=3$, 主流方向突起幅 $L / h=2$, スパン方向突起幅 $W / h=2$ と設定した.

格子は突起間すきまにより $190 \times 55 \times(175 ＼mathrm{~ 191) ~ の ~}$ 非一様直交格子を使用した。 また，計算は突起間すき ま $s / h=0.2,0.5,1.0,2.0$, レイノルズ数 $R e=100 \sim$ 500, プラントル数 $P r=0.7$ について行った. 流れ が非定常の場合 $(s / h=0.2$ の $R e \geq 300, s / h=0.5$, 1.0 の $R e \geq 400)$ は流れが周期的になった後サンプリ ングを開始した. なお, $s / h=2.0, R e=500$ につい て, $160 \times 43 \times 161,190 \times 55 \times 191,210 \times 65 \times 221$ の 3 種類の格子を用いて予備計算を行い, 細かい 2 格子 で格子依存性がないことを確認している.

\section{4. 結果および考察}

本計算の妥当性を検証するため, 得られた瞬間流線 を可視化写真 ${ }^{(33)}$ と比較して図 2 に示す. 本計算結果 


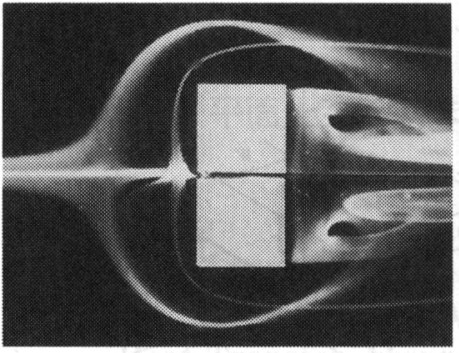

$s / h=0.14, R e=170$

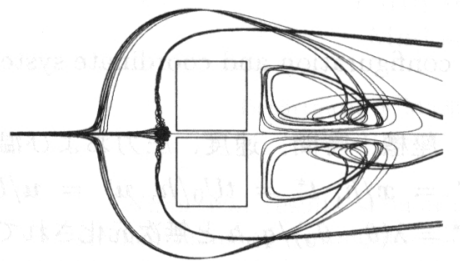

$s / h=0.2, R e=200$

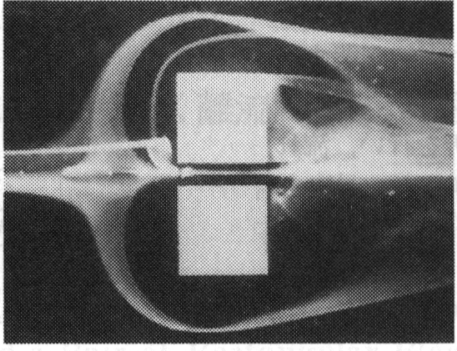

$s / h=0.57, R e=170$

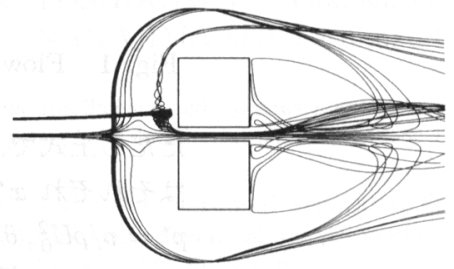

$s / h=0.5, R e=200$

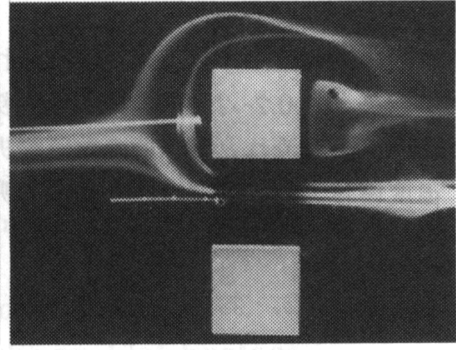

$s / h=2.00, R e=170$

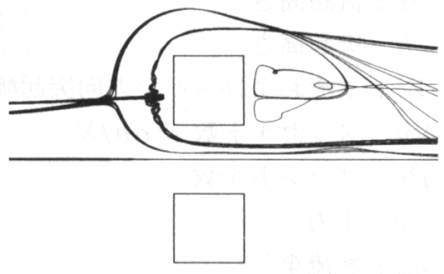

$s / h=2.0, R e=200$

Fig. 2 Comparison of flow pattern

$s / h=0.2$

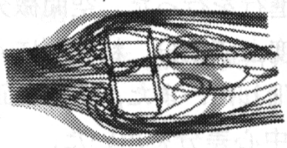

$s / h=0.2$

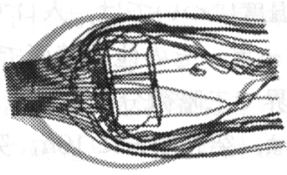

0.5

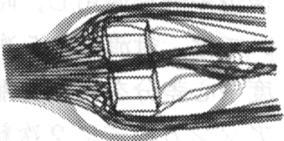

(a) $R e=200$

0.5

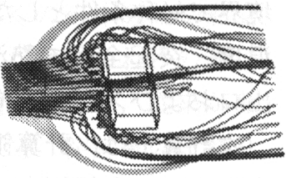

1.0

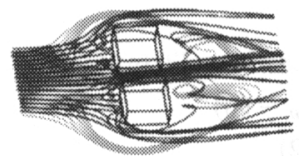

1.0

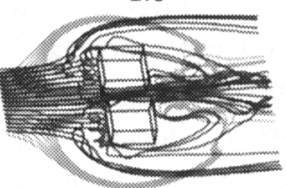

2.0
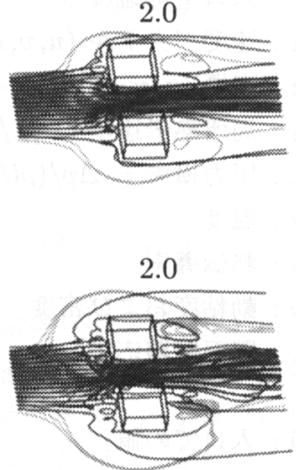

(b) $R e=500$

Fig. 3 Variation of streamline with $s$

は実在の流れ場をよく再現している. $s / h=0.2$ の場 合, 突起対まわりの流れはスパン方向長さ $2 W$ の直 方体まわりの流れと類似しており, 突起対を包み込む 1個の大きな馬蹄形渦が形成されている. 突起間すきま が広がると，それぞれの突起まわりに馬蹄形渦が形成 され，突起間すきま内で強く干渉している. $s / h=2.0$ の場合, 突起まわりの流れの様相は単一突起の結果 (20) に近づいているが, 流路中央付近の流体は突起後方の 循環領域に巻き込まれないことがわかる.

図 3 に突起対まわりの流れの様相を示す. $R e=200$ の場合, $s / h=0.2$ では下壁近傍の流体は突起間すき まに流入できず, 突起対外側に大きく回り込み, 突起 対後方の循環領域に巻き込まれ，その後下流一と流れ
去っている. 流路中央の突起間すきまに流入する流れ は上方に強く押し上げられている. $s / h=0.5$ では流 路中央の流体は突起間すきまを通り, 循環領域の影響 を受け流れの方向を大きく変えるのに対し, $s / h=2.0$ ではほぼそのまま下流入流れている， Re $=500$ の場 合，下壁付近の流体は突起対外側にさらに大きく回 り込み, $s / h=0.2,0.5$ では循環領域に巻き込まれて いない. また, 突起後方の循環領域での流れの様相は $R e=200$ よりさらに複雑になっている.

図 4 に流路中央（左図）および突起中央（右図）に おける下壁での壁面摩擦係数分布 $C_{f x}$ を示す. 壁面摩 擦係数が負の領域では下壁近傍に時計まわりに回転す る渦が形成され, 逆流が生じている， $R e=200$ の場 

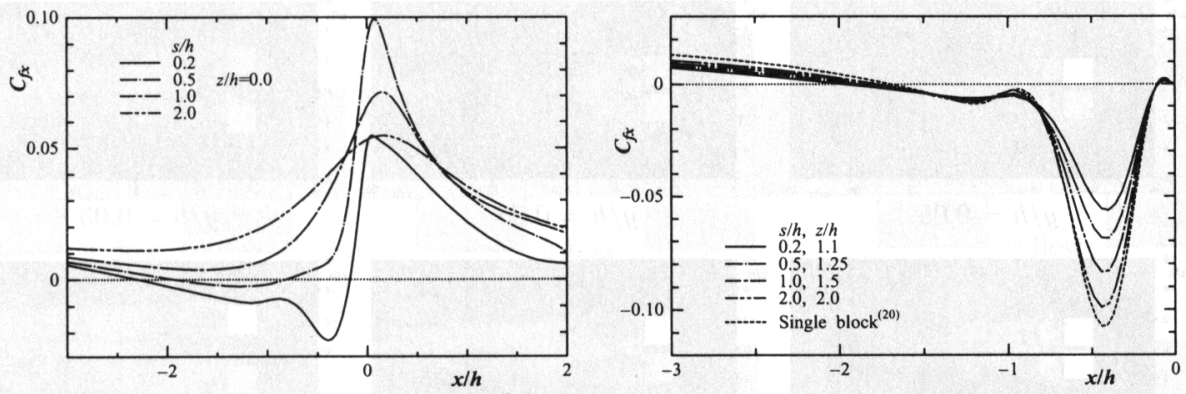

(a) $R e=200$
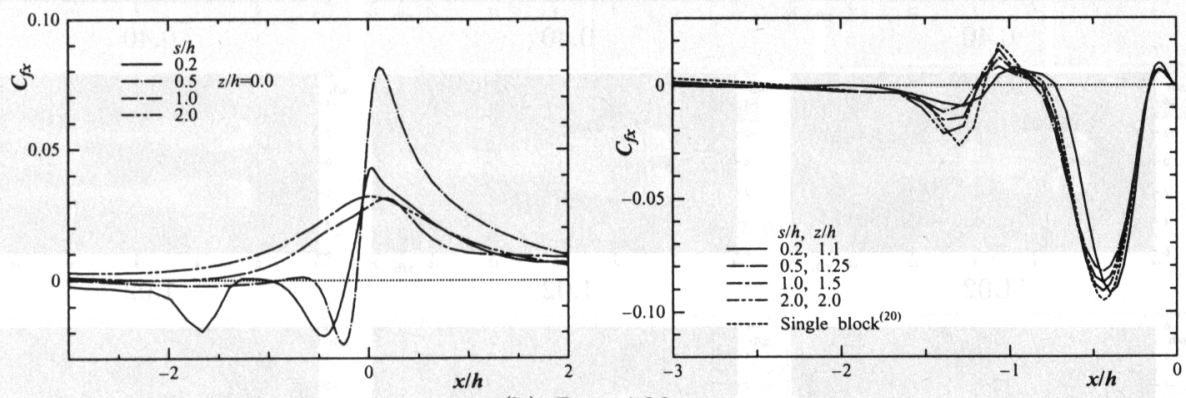

(b) $R e=500$

Fig. 4 Distribution of surface skin friction coefficient

$s / h=0.2$
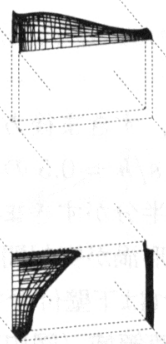

$s / h=0.2$

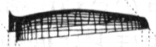

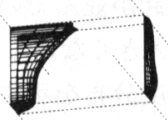

0.5
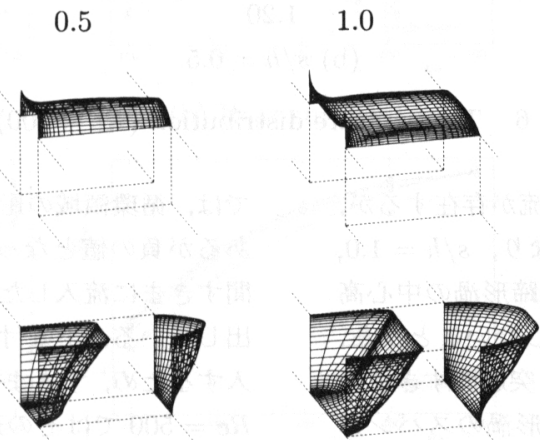

(a) $R e=200$

0.5
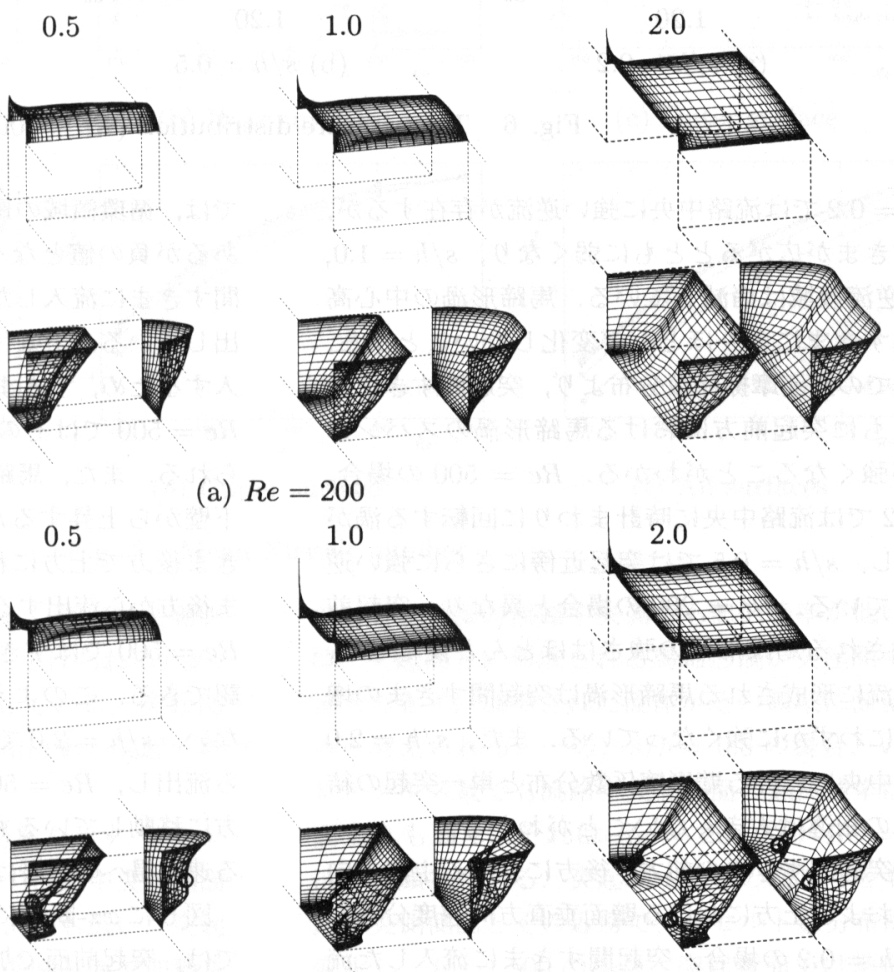

(b) $R e=500$

Fig. 5 Distribution of velocity 


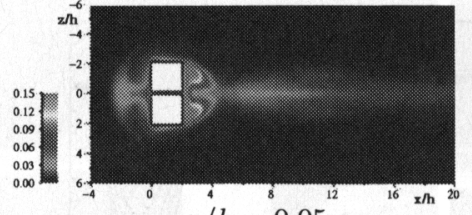

$y / h=0.05$

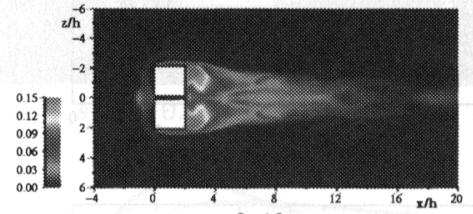

0.40

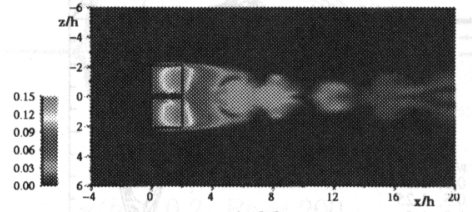

1.02

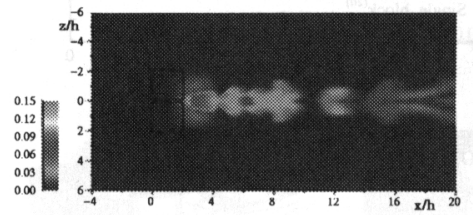

1.20

(a) $s / h=0.2$

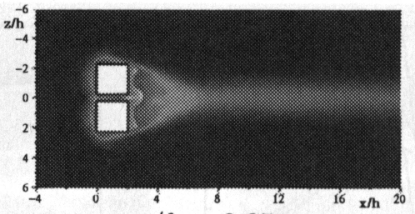

$y / h=0.05$

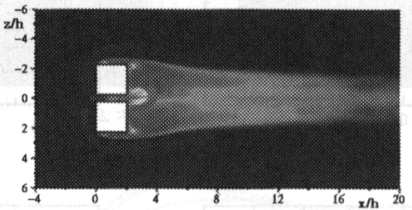

0.40
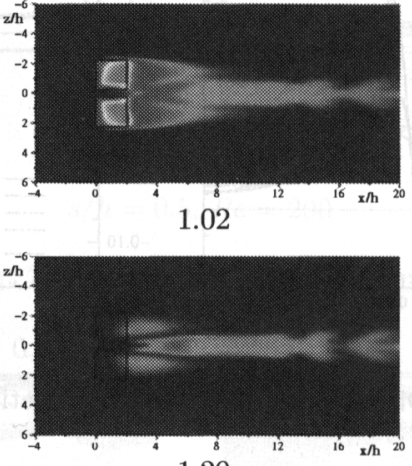

1.20

(b) $s / h=0.5$

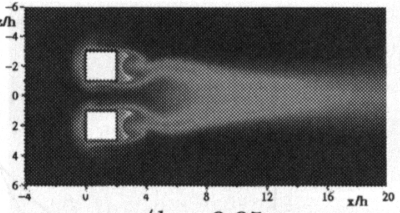

$y / h=0.05$

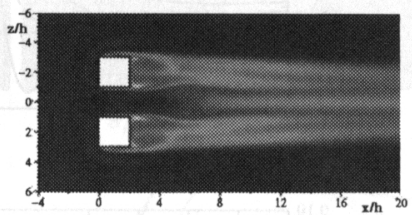

0.40
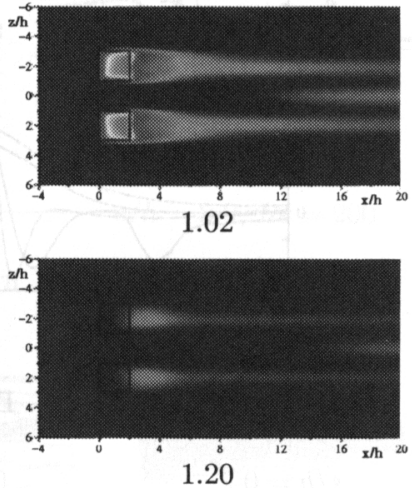

(c) $s / h=2.0$

Fig. 6 Temperature distribution $(R e=500)$

合, $s / h=0.2$ では流路中央に強い逆流が存在するが, 突起間すきまが広がるとともに弱くなり, $s / h=1.0$, 2.0 では逆流領域は消减している．馬蹄形渦の中心高 さは突起すきまによりほとんど変化しないことから， 突起中央での壁面摩擦係数分布より, 突起間すきまの 増加とともに突起前方における馬蹄形渦のスパン方 向渦度が強くなることがわかる. $R e=500$ の場合, $s / h=0.2$ では流路中央に時計まわりに回転する渦が 2 個存在し, $s / h=0.5$ では突起近傍にさらに強い逆 流が生じている. $R e=200$ の場合と異なり, 突起前 方に形成される馬蹄形渦の強さはほとんど変化せず, さらに上流に形成される馬蹄形渦は突起間すきまの増 加とともにわずかに強くなっている. また, $s / h=2.0$ での突起中央における壁摩擦係数分布と単一突起の結 果 ${ }^{(20)}$ との相違は大きくないことがわかる.

図 5 に突起間すきまの前方，後方に扔ける主流方向 速度分布および上方における壁面垂直方向速度分布を 示す. $s / h=0.2$ の場合, 突起間すきまに流入した流 体の大部分はすきま後方から流出できず，すきま上方 から流出していることがわかる. しかも， $R e=200$
では，循環領域の影響を受け，すきま後方でわずかで あるが負の値となっている. $s / h=0.5$ の場合, 突起 間すきまに流入した流体の約半分がすきま後方から流 出している. 下壁付近の馬蹄形渦が突起間すきまに流 入するため, すきま前方の流れは下壁付近で増速され， $R e=500$ ではその近傍に低速領域（図中○印）が見 られる。また，馬蹄形渦が突起間すきまを流れる間に 下壁から上昇するため, $R e=500$ ではこの領域がす きま後方で上方に移動している. $s / h=1.0$ ではすき ま後方から流出する流体の割合がさらに増加している. $R e=500$ ではすきま後方の中ほどに低速な領域が確 認できる.このような特徵は $R e=200$ では現れてい ない. $s / h=2.0$ では, 流体の大部分はすきま後方か ら流出し, $R e=500$ では低速領域がすきま後方で上 方に移動しているものの，突起が並んでいることによ る速度場への影響はそれほど大きくないことがわかる。

図 6 に $x z$-断面における温度分布を示す。下壁付近 では, 突起前面で加熱された流体が馬蹄形渦により突 起前方一と移動している. 外側側面上では，流れが突 起角部ではく離しその近傍で循環するため, 温度境界 

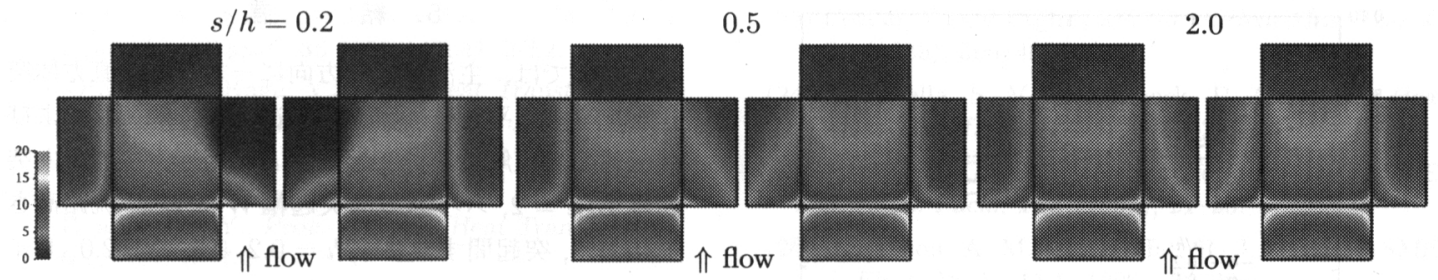

(a) $R e=200$
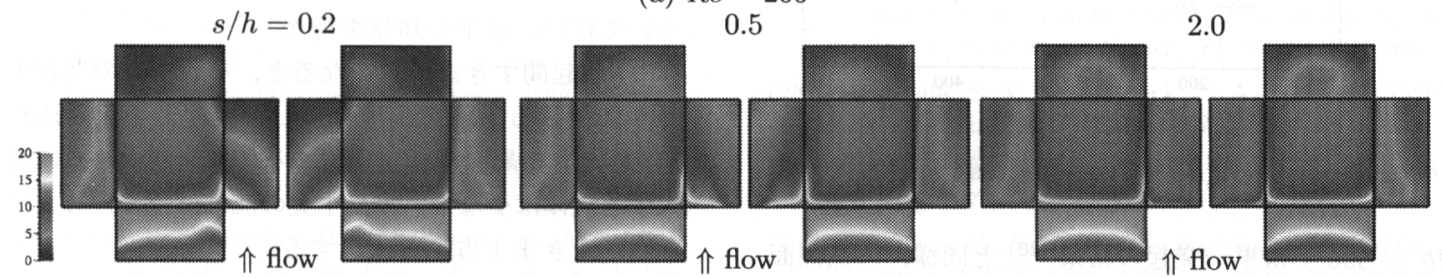

(b) $R e=500$

Fig. 7 Distribution of local Nusselt number

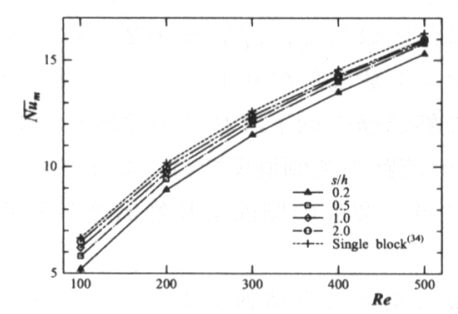

(a) Front surface

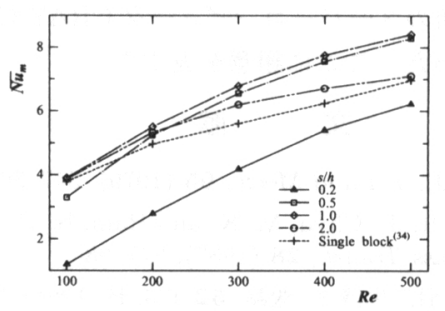

(d) Inner surface

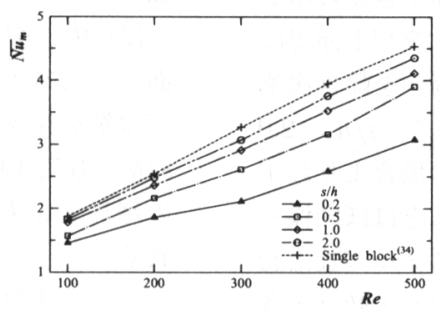

(b) Rear surface

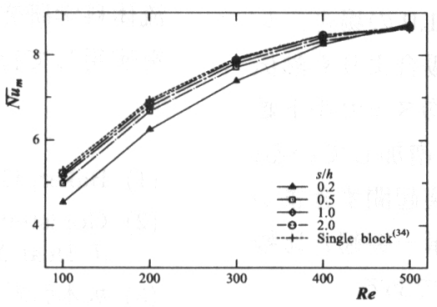

(e) Upper surface

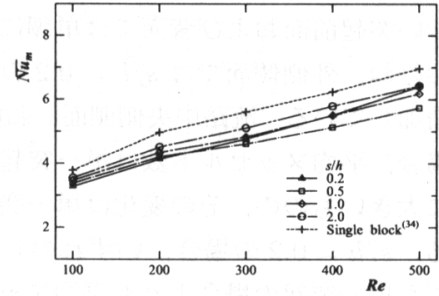

(c) Outer surface

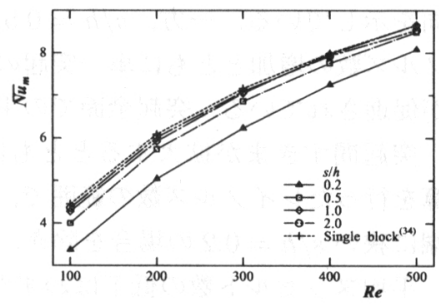

(f) All surfaces

Fig. 8 Mean Nusselt number

層が厚くなっている. $s / h=0.2$ では, 流路中央側側 面で加熱された流体が上方に強く押し上げられるため, $y / h=1.20$ にも高温の領域が存在している. 突起間 すきまの増加とともに, 温度場の様相は単一突起の結 果 ${ }^{(20)}$ に近づいている.

図 7 に時間平均局所ヌッセルト数分布を示す. $s / h=$ 0.2 の場合, いずれのレイノルズ数でも流路中央側側面 では熱伝達率の低い領域が外側側面よりも広い. 突起 間すきまに流入した流体は, 流路中央側側面で加熱さ れた後, すきま上方から流出するため, 突起上面の流 路中央側で熱伝達率が低下している. また， $R e=500$
では突起前面の流路中央側でも熱伝達率が低い。これ は，突起前方に形成される馬蹄形渦が突起間すきまに 流入できず, 加熱された流体がその領域に滞留するた めと考えられる. 一方, $s / h=0.5$ の場合, いずれの レイノルズ数でも流路中央側側面の熱伝達率は外側側 面よりも高く, それは $R e=200$ より $R e=500$ の ほうが顕著である．突起間すきまの増加とともに，流 路中央側側面とその近傍でヌッセルト数分布は大きく 変化し, $R e=500$ の場合, 突起背面では熱伝達が最 大となる位置が流路中央側から突起中央へと移動して いる．しかしながら，他の面での相違は大きくなく， 


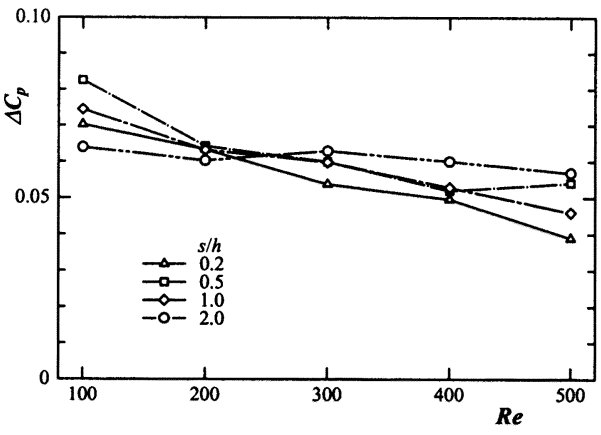

Fig. 9 Pressure loss

$R e=500$ では単一突起の結果 ${ }^{(20)}$ と同様, 外側側面 下部で熱伝達が促進されている.

図 8 にレイノルズ数による突起各面および全面での 平均ヌッセルト数の変化を, 単一突起の結果 ${ }^{(34)}$ と比 較して示す. 平均ヌッセルト数は突起間すきまの增加 に伴い突起前面および背面では単調に, 突起上面では おおむね，外側側面では $s / h=0.2$ の場合を除き次第 に増加している. 流路中央側側面において, $s / h=2.0$ の場合, 平均ヌッセルト数は単一突起の場合よりわず かに大きいものの, その変化は単一突起とほぼ同様で ある. $s / h=0.2$ の場合, いずれのレイノルズ数にお いても単一突起の場合よりも平均ヌッセルト数は小さ いが, レイノルズ数の増加とともにその差は縮小する 傾向を示している. 一方, $s / h=0.5,1.0$ の場合, レ イノルズ数の増加とともに単一突起の場合よりも熱伝 達が促進されている. 突起全面での平均ヌッセルト数 は，突起間すきまが拡大するとともに増加している. 計算を行ったレイノルズ数の範囲で，突起間すきまが 極端に狭い $s / h=0.2$ の場合を除き, 単一突起と比較 し, 平均ヌッセルト数の低下はわずかである.

図 9 に圧力損失のレイノルズ数による変化を示す. $\Delta C_{p}$ は, 計算領域の入口と出口における平均圧力の差 から, 突起対がない場合の圧力損失を差し引いたもの である. $s / h=0.2,1.0$ の場合, 圧力損失はレイノル ズ数の増加とともに単調に減少している. $s / h=0.5$ の場合, 圧力損失はほぼ同様に変化するが, $R e=500$ でわずかに増加している. この増加は, 図 8(b) に示す $s / h=0.5$ の場合の突起背面での平均ヌッセルト数の 増加率が $R e=400 \sim 500$ の範囲で変化していること から，突起背面に形成される循環領域が縮小するため と考えられる. 一方, 突起間すきまの広い $s / h=2.0$ の場合, レイノルズ数による圧力損失の変化は小さい. また, 圧力損失の突起間すきまによる変化はレイノル ズ数に依存していることがわかる.

\section{5. 結}

本研究では，主流と直交方向に一対の同一直方体突 起物を有する平行壁面流路内三次元はく離流れおよび 熱伝達の数值解析を, 突起高さ $h$ に対し, 主流方向突 起幅 $L / h=2$, スパン方向突起幅 $W / h=2$, 流路高さ $H / h=3$, 突起間すきま $s / h=0.2,0.5,1.0,2.0$, レイ ノルズ数 $R e=100 \sim 500$, プラントル数 $\operatorname{Pr}=0.7$ に ついて行い, 以下の知見を得た.

(1) 突起間すきまが狭くなると，それぞれの突起ま わりに生じる馬蹄形渦は合体し，突起対を包み込む 1 個の大きな馬蹄形渦を形成する. 突起間すきまに流 入する流体は少なく, 流路中央の流れは強く押し上げ られ，すきま上方から流出する.

(2) 突起背面の循環領域での流れは突起間すきまお よびレイノルズ数により大きく変化する. $s / h=0.5$, 1.0 では，突起間すきまに流入した馬蹄形渦は互いに 強く干涉し，すきま内の流れを複雑にする.

(3) 単一突起と比較して, $s / h=0.2$ では突起全 面の平均ヌッセルト数はかなり小さいが, $s / h \geq 0.5$ では突起全面の熱伝達の低下はわずかである。また， $s / h=0.5,1.0$ の流路中央側側面では, レイノルズ数 の増加とともに単一突起の側面より熱伝達が促進さ れる.

なお，本計算は東北大学情報シナジーセンターの スーパーコンピュータ SX-4/128H4, および東北大学 流体科学研究所のスーパーコンピュータ CRAY-C916 を使用して行った．ここに謝意を表する.

\section{文献}

(1) Baker, C. J., J. Fluid Mech., 95 (1979), 347-367.

(2) Goldstein, R. J., Chyu, M. K. and Hain, R. C., Int. J. Heat Mass Transf., 28 (1985), 977-985.

（3）坂本弘志 - 羽二生博之, 機論, 52-473, B (1991), 290297.

(4) Fisher, E. M. and Eibeck, P. A., Trans. ASME, J. Heat Transf., 112 (1990), 329-335.

(5) Baker, C. J., Trans. ASME, J. Fluids Eng., 113 (1991), 489-495.

(6) Chyu, M. K. and Natarajan, V., Trans. ASME, J. Heat Transf., 113 (1991), 851-857.

(7) Natarajan, V. and Chyu, M. K., Trans. ASME, J. Heat Transf., 116 (1994), 552-560.

(8) Seal, C. V., Smith, C. R., Akin, O. and Rockwell, D., J. Fluid Mech., 286 (1995), 117-135.

(9) Tropea, C. D. and Backstatter, R., Trans. ASME, J. Fluids Eng., 107 (1985), 489-494.

(10) Davalath, J. and Bayazitoglu, Y., Trans. ASME, J. Heat Transf., 109 (1987), 321-328.

(11) Shaw, H. J., Chen, W. L. and Chen, C. K., Trans. ASME, J. Elect. Pack., 113 (1991), 40-49. 
(12) Kim, S. Y., Sung, H. J. and Hyun, J. M., Int. J. Heat Mass Transf., 35 (1992), 2941-2952.

(13) Ota, T. and Kaga, Y., Proc. Heat Transf. 3rd UK National Conf. Incorporating 1st European Conf. Thermal Sci., 2 (1992), 797-804.

(14) Matsubara, K., Suzuki, K., Treidler, E. B., Suzuki, H. and Mae, Y., Proc. 10th Int. Heat Transf. Conf., 6 (1994), 73-78.

(15) Morris, G. K. and Garimella, S. V., Exp. Therm. Fluid Sci., 12 (1996), 65-74.

(16) Nakajima, M. and Ota, T., Proc. Transport Phenomena in Thermal Sci. Process Eng., (1997), 233-237.

（17）太田照和・中島円・柳岡英樹, 機論, 64-617, B (1998), 226-231.

(18) Ota, T., Yanaoka, H. and Nakajima, M., Proc. ASME/JSME Thermal Eng. Jt. Conf., 1 (1995), 313-320.

(19) Nakajima, M. and Ota, T., Proc. 11th Int. Heat Transf. Conf., 3 (1998), 133-138.

（20）中島円・柳岡英樹 - 太田照和, 機論, 64-628, B (1998), 4116-4121.

（21）中島円·太田照和, 機論, 65-637, B (1999), 3111-3116.

(22) Sparrow, E. M., Yanezmoreno, A. A. and Otis, D. R. Jr., Int. J. Heat Mass Transf., 27 (1984), 469473 .
(23) Asako, Y. and Faghri, M., Int. J. Heat Mass Transf., 32 (1989), 395-405

(24) Garimella, S. V. and Eibeck, P. A., Int. J. Heat Mass Transf., 33 (1990), 2659-2669.

(25) Lehmann, G. L. and Pembroke, J., Trans. ASME, J. Elect. Pack., 113 (1991), 21-26.

(26) Anderson, A. M. and Moffat, R. J., Trans. ASME, J. Elect. Pack., 114 (1992), 22-28.

(27) Meinders, E. R., Van Der Meer, T. H. and Hanjalic, K., Int. J. Heat Mass Transf., 41 (1998), 335-346.

(28) Garimella, S. V. and Eibeck, P. A., Trans. ASME, J. Elect. Pack., 113 (1991), 367-373.

(29) 岡本史紀 - 勝間田知英 - 安部信明 - 木島正道, 機論, 63616, B (1997), 3834-3842.

(30) Nakajima, M., Yanaoka, H., Yoshikawa, H. and Ota, T., Proc. FEDSM'00, ASME, (2000), FEDSM0011003.

(31) Ota, T. and Yanaoka, H., Proc. 5th Int. Symp. Comput. Fluid Dyn., 3 (1993), 423-428.

(32) Amsden, A. A. and Harlow, F. H., J. Comput. Phys., 6 (1970), 322-325.

(33) Nakajima, M., Ueda, K., Mori, M., Ito, Y. and Ota, T., Proc. PSFVIP-3, (2001), F3008.

(34) 中島円, 東北大学博士論文, (1999). 